\title{
Empowerment Patterns of Leaders in ICT and School Strengths Following the Implementation of National ICT Reform
}

\author{
Orit Avidov-Ungar \\ Achva Academic College \\ Open University of Israel, \\ Israel \\ oritav@openu.ac.il
}

\author{
Tamar Shamir-Inbal \\ Ministry of Education \\ Haifa University, \\ Haifa, Israel \\ shamirt@gmail.com
}

\section{Executive Summary}

The Ministry of Education in Israel has, over the past two years, been running an education program designed to lead the implementation of ICT (Information and Communications Technology) in schools. Implementation of the program is accompanied by training and support of teachers selected to be ICT leaders. The role of the ICT leader is divided to two positions: (1) the School ICT Coordinator, in charge of ICT reform at their school, and (2) the Regional ICT Advisor, in charge at the district level and operating in several schools. Participants in the current research were 226 ICT leaders from one of the districts in Israel that participated in the ICT reform. The purpose of the study was to evaluate the contribution of the ICT reform on schools' ICT leaders and schools' strengths. We also had a theoretical basis for assuming that the ICT leaders will experience personal empowerment as a result of their position and training. Thus, we set out to evaluate the personal empowerment patterns of ICT leaders and how they relate to the schools' strengths. The strengths were identified using content analysis on ICT leaders' perceptions of the schools' strengths. This analysis revealed nine fields in which the schools improved following the ICT plan: information sharing, student empowerment, dialogue, technological assimilation, teacher empowerment, management optimization, pedagogical change, bridging the gaps, and community visibility. These nine fields were categorized to three aspects of school change following ICT reform: pedagogical, technological, and organizational aspects. The personal empowerment of the ICT leaders was measured with an online questionnaire in which the ICT leaders reported their sense of learning and satisfaction as leaders of organizational change. This served as a measure of personal empowerment in the pedagogical and technological domains. The results showed that ICT leaders who reported pedagogical change at school also had significantly higher pedagogical and technological personal empowerment. We assume that these results represent a gradual model, in which the pedagogical strength is the end stage of the ICT implemen-

Material published as part of this publication, either on-line or in print, is copyrighted by the Informing Science Institute. Permission to make digital or paper copy of part or all of these works for personal or classroom use is granted without fee provided that the copies are not made or distributed for profit or commercial advantage AND that copies 1) bear this notice in full and 2) give the full citation on the first page. It is permissible to abstract these works so long as credit is given. To copy in all other cases or to republish or to post on a server or to redistribute to lists requires specific permission and payment of a fee. Contact Publisher@,InformingScience.org to request redistribution permission. tation process. The findings highlight the importance of providing professional guidance for ICT leaders as messengers of innovative pedagogical perception in schools following ICT implementation. Also, they shed light in the process of ICT implementation and can help construct new ways of evaluating such processes. 
Keywords: Empowerment, leaders in ICT, school's strengths, innovative pedagogy, TCPK (Technological and Pedagogical Knowledge), ICT reform.

\section{Introduction}

The digital age we live in leads to the introduction of far-reaching changes that affect the way we live. Educators around the world and in Israel are looking for ways to adapt the education system to the social and cultural changes following the digital age (Avidov-Ungar \& Eshet-Alkalai, 2011a, 2011b; Kozma, 2008).

For the last two years, the Israeli Ministry of Education has been running an educational program called "Adjusting the education system to the 21 st century". The purpose of this program is to implement innovative technology in schools in order to improve the quality of teaching and learning. This program has a comprehensive approach which focuses on organizational, technological, and pedagogical aspects. The main elements of the program are the following: integrating ICT in the learning environment; using the school's portal as a communication tool between school staff, parents and students; digital communication within the school community and beyond; implementing online pedagogical management systems; and practice on ethics issues regarding the use of ICT (Israeli Ministry of Education, 2012). The national ICT program is being implemented in Israel in the years 2010-2012 to approximately 800 schools in two districts.

Implementation of the program in schools is accompanied by guidance and support of teachers selected to be ICT leaders. There are two ICT leader positions. The first, called "School ICT Coordinator", are school teachers selected by the Ministry of Education to lead the national ICT reform at the school level. The School ICT Coordinator is a key figure in school and the principal's "right hand" in every aspect of instilling a culture of ICT in the school. In the technological domain, the School ICT Coordinator serves as a guide for teachers, helping them acquire new technological tools. In the pedagogical domain, the Coordinator's role is to guide teachers to use ICT in an intelligent way and incorporate this tool in their lessons. This role requires both guidance on the ICT material available for the teachers and instructing them on how to design their own ICT-based lessons. The main purpose is to incorporate ICT in a way that provides added value to the pedagogy. In the organizational- managerial domain, the School ICT Coordinator is involved in decision making and helps the principal to monitor the performance required within the program outputs. The second position is "Regional ICT Advisor". These are ICT leaders who function at the regional level. Each Regional ICT Advisor is in charge of numerous schools, and the advisors' role is to be the link between the national program requirements and the needs of every specific school. Thus, the advisors can serve as a "bridge" that can help facilitate the successful implementation of ICT reform in schools. The Regional ICT Advisor works with the principal and the School ICT Coordinator to provide guidance and support in the pedagogical, technological and organizational-managerial domains.

In order to ensure that the ICT leaders were suitable to lead the national ICT reform, they had to acquire Technology Pedagogy Content Knowledge (TPCK). This knowledge is critical for the effective implementation of innovative technology in schools (Doering, Veletsianos, Scharber, \& Miller, 2009; Mishra \& Koehler, 2006; Polly \& Mims, 2009) and is critical for their personal empowerment as leaders of an organizational change (Cribner, Truell, Hager, \& Srichai, 2001).

In educational systems, there is often an in-built resistance to organizational change. This resistance is ingrained in the structure, culture and climate of the school (Carter, 2008; Fullan, 2001; Levin \& Fullan, 2008). Studies conducted on the implementation of innovative technologies at schools reveal that the implementation process is often established in a top-down manner. In this top-down process, the teachers' opinions are not taken into account (Levin \& Fullan, 2008; Tyack \& Cuban, 1995) and there is no consideration given to the organization's previous practice, 
norms, and past experience with unsuccessful technological reforms (Levin \& Fullan, 2008; Ogobonna \& Harris, 2003; Vaillant, 2005; Zimmerman, 2006). Successful ICT implementation involves many factors (Hargreaves \& Goodson, 2006) and is related to substantial cultural and organizational change (Sarason, 1995; White, 2007), in which change is taking place at all levels of the organization and in its fundamental assumptions. The role of the ICT leader is critical for the effective implementation of organizational change, since the leaders serve as the key figures that can facilitate change in which ICT will become an integral part of the school's norms and practices (Shamir-Inbal, Dayan, \& Kalli, 2009).

Studies reveal that ICT implementation occurs at different rates and in different ways according to the teacher's specific profile (Mioduser, Nachmias, Forkosh, \& Tubin, 2004; Peled, Kali, \& Dori, 2007), but also in accordance with the school's attitudes toward ICT as a tool for pedagogical improvement (Shamir-Inbal et al., 2009). Also, it is known that the inclusion of teachers as ICT leaders and their sense of empowerment play a significant role in the successful implementation of ICT at the school level (Avidov-Ungar \& Eshet-Alkalai, 2011a; Vaillant, 2005).

Empowerment reflects an interactive process which occurs between the individual and his environment (Kieffer, 1983). The teacher undergoes a process of empowerment as a result of his own personal and professional development (Darling-Hammond \& Bransford, 2005; Day \& Gu, 2007). Thus, teacher empowerment is related to the specific circumstances each teacher experiences during his own professional development (Fraser, Kennedy, Reid, \& Mckinney, 2007; Kennedy, 2005). The sense of empowerment is reflected through internal and external changes that empowered teachers undergo (Darling-Hammond, Wei, Andree, Richardson, \& Orphanos, 2009). The empowerment is a process that is motivated by the teacher, co-workers, school organization, and the nature of the interpersonal relationships at the workplace (Edwards, Green, \& Lyons, 2002). This means that empowerment is a process that can be achieved by the individual itself, but is also enhanced through the organization and thus contributes to higher self-evaluation and more productivity at the organizational level (Hargreaves, 2005).

Studying the factors that affect the sense of empowerment can assist in understanding the contribution organizational changes have on personal empowerment (Kuijpers, Houtveen, \& Wubbels, 2010). According to Avidov-Ungar \& Friedman (2011) the main factors contributing to a sense of empowerment are the following: understanding the job requirements- teachers who felt empowered were those who defined their professional success as resulting from their profound understanding of their job requirements and expectations of them in that position; receiving system functions in the early stages of their career - empowered teachers were those who received additional responsibilities early in their career, leading to a sense of achievement and development in the organizational ranks; understanding experience is a significant human resourceempowered teachers acknowledged their career experience as a fundamental part of their professionalism and as a means towards development up the organizational ranks; positive selfperception - the literature defines "self-perception" as the overview one has of one's own abilities (Pajares \& Miller, 1994). This overview is a complex evaluation, which is based on an individual's direct and indirect attempts at self-evaluation and on how that individual is perceived by his significant others (Bandura, 1997). Thus, feeling empowered involves a strong belief in one's professional abilities and positive feedback from supervisors and co-workers. Growthpromoting school framework- from teachers' interviews it seems that educational growth is a key variable in one's sense of professional empowerment. The school framework, whether it is academic or professional, is important for growth and development. During this learning process teachers can achieve a reflective and retrospective approach on their own learning and practice during their careers (Pajares \& Miller, 1994). The teachers mentioned this as a key element in their personal and professional development. Viewing the school as an organizational-systemic framework - most teachers perceive their role in a focused manner as in charge of classroom 
instruction. However, teachers who were assigned additional responsibilities early in their career perceived their professional position as a more complex one that can have an effect both on the classroom and the school as an organization. This systemic approach strengthens the sense of competence and enhances self-empowerment. Based on the factors of empowerment mentioned above, we have strong reason to assume that teachers receiving the position of "ICT leaders" are undergoing a process of professional empowerment resulting from their organizational position and educational training.

The inclusion of ICT leaders in schools has been acknowledged as a key element in successful ICT implementation (Fishman, Marx, Blumenfeld, Krajcik, \& Soloway, 2004). The person chosen for the position of ICT leader should be a person with leadership qualities and be reliable and responsible. Also, these individuals should be involved in decision-making processes, receive full support from their superiors, and be part of a professional learning community (HadjithomaGarstka, 2011). The incorporation of an ICT leader who serves not only as a technological guide, but also helps school staff to integrate ICT as part of their daily job routine and as a pedagogical tool, is of great importance to schools. This helps teachers to better integrate ICT in their classrooms and enables more teachers to be a part of this change, not only those considered as being "groundbreaking" teachers (Newhouse, 2010; Shamir-Inbal et al., 2009).

It is worth mentioning that all of the ICT leaders in this research are qualified teachers with technological knowledge and experienced in implementation processes of ICT in educational domains. Those chosen as ICT leaders have accepted upon themselves this position, fully aware of the challenges such a role requires. Also, they were fully cooperative during their training. Thus, the assumption was that they will experience empowerment during their year of training and working as ICT leaders.

The main goal of this current research was to characterize the schools' strengths following ICT implementation, as perceived by the ICT leaders themselves. Also, the research set out to reveal whether and how the personal empowerment of the ICT leaders will be related to the schools' strengths following ICT implementation.

\section{Methodology}

\section{Research Objectives}

This study's goal is to examine the relationship between the personal empowerment experienced by ICT leaders and the schools' strengths following ICT implementation. Based on the assumption that ICT leaders are undergoing a process of personal empowerment, this research distinguishes between two dimensions of personal empowerment. The first, "technological empowerment", is manifested in providing innovative tools, knowledge, and skills as leaders of the technological assimilation process at the school. The second, "pedagogical empowerment", is manifested in the understanding of the added value of ICT in teaching and a sense of leadership in the pedagogical domain. These personal empowerment dimensions will be evaluated in regard to their possible connection with school strengths following ICT implementation.

\section{Participants}

The study was performed on one of the two districts in Israel that took part in the national ICT plan. A total of 226 ICT leaders participated (representing $46 \%$ of the total number of ICT leaders in the district). The ICT leaders were divided to three groups according to their position or seniority: School ICT Coordinators - new; School ICT Coordinators - senior; and Regional ICT Advisors. See Table 1 for a more detailed description of the groups. 
Table 1: Description of the ICT leaders who participated in this study.

\begin{tabular}{|l|l|l|r|}
\hline \multicolumn{1}{|c|}{ Group name } & Level & \multicolumn{1}{c|}{$\begin{array}{c}\text { Number of years in the national } \\
\text { ICT plan }\end{array}$} & $\begin{array}{r}\text { Respondents } \\
\hline \text { Regional ICT Advisors }\end{array}$ \\
& regional & $\begin{array}{l}30 \%-\text { second year } \\
70 \%-\text { first year }\end{array}$ & $41 / 90$ \\
\hline School ICT Coordinators- senior & school & second year & $43 / 100$ \\
& & & $43 \%$ \\
\hline School ICT Coordinators- novice & school & first year & $142 / 300$ \\
& & & $47 \%$ \\
\hline Total ICT leaders & & & $\mathbf{2 2 6 / 4 0 0}$ \\
& & & $\mathbf{4 6 \%}$ \\
\hline
\end{tabular}

During their training for the position, the ICT leaders received close guidance. Their guidance included group meetings, distance learning sessions, regular visits to the school, and individual help as needed. Also, all of the ICT leaders took part in a yearly education program (2011-2012) that constitutes sixty hours of training. The education program provided innovative Technological Pedagogical Knowledge (TCPK) and enhancement of their training skills. Thus, during this year of training, they acquired new technological skills, participated in collaborative work in an elearning community, and practiced the development and evaluation of ICT-based lessons.

\section{Measures}

The measures in this research were based on an online questionnaire that the ICT leaders completed at the end of their training within the national ICT plan. The questionnaire included statements relating to the sense of personal satisfaction and learning of the ICT leaders. In the present study the questionnaire was divided into two parts, the technological and the pedagogical domains. The questions relate to the ICT leaders' sense of learning and satisfaction as leaders of organizational change and serve as a measure of personal empowerment in each of these domains:

1. a. Technological empowerment: Determined according to statements that referred to the sense of satisfaction and learning ICT leaders experienced in the technological domain. These items were scored on a Likert scale from 1 = "not at all" to 5= "very much":

- $\quad$ The experience enriched me in the technology domain.

- $\quad$ The experience benefited my field work.

The internal consistency of these items was Cronbach's alpha $=0.77$

1. b. Pedagogical empowerment: Determined according to statements that referred to the sense of satisfaction and learning ICT leaders experienced in the pedagogical domain. These items were scored on a Likert scale from 1 = "not at all" to 5= "very much":

- $\quad$ The experience enriched me in the pedagogical domain.

- $\quad$ The training inspired me to continue learning.

- $\quad$ The meetings exposed me to a wide variety of ideas.

- $\quad$ The training contributes to my skills as a leading teacher in the field of assimilating 21st century skills. 
The internal consistency of these items was Cronbach's alpha $=0.90$

2. An open-ended question in which the ICT leaders are asked to describe "at least one significant strength in the school following the implementation of ICT during this past year." This question served to analyze the school's strengths as perceived from the point of view of those in charge of leading the organizational change.

\section{Data Analysis}

\section{Content analysis}

The analysis of school strengths is based on the assumption that qualitative analysis can enable a reflective process (Kaufman, 2009) in which professionals can learn to observe and understand their process of personal and professional development (Creswell, 2007). Thus, the analysis in this research focused on the school strengths as perceived by the ICT leaders and contained no apriori assumptions of the researchers. In the initial analysis, school strengths were classified according to the common denominator between the various answers.

In the second stage, these strengths were classified into three high-level categories for further statistical analyses.

\section{Statistical analysis}

SPSS v.16 was used in order to study the possible relationships between the personal empowerment patterns of the ICT leaders and the school strengths, as revealed in the content analysis.

Since the school strengths are drawn from qualitative analysis, they can serve only as a categorical variable in the analysis. Thus, we used ANOVA analysis to reveal possible differences between groups. The finding of significant differences between the different school strengths in the dependent variables of personal empowerment will allow us to assume a correlative connection between the personal empowerment of ICT leaders and the schools' strengths following ICT implementation.

\section{Results}

\section{Empowerment Patterns of ICT Leaders}

One way ANOVA was performed to detect differences in the level of personal empowerment as a function of ICT leader position. This analysis revealed significant differences between ICT groups on the level of technological $[\mathrm{F}(2,225)=4.81, \mathrm{p}<.01]$ and pedagogical $[\mathrm{F}(2,225)=4.81$, $\mathrm{p}<.01]$ empowerment. Post hoc comparisons using Tukey's test found that senior School ICT Coordinators experienced higher levels of personal empowerment in the technological and pedagogical domain in comparison to novice School ICT Coordinators.

As revealed by t-tests, novice School ICT Coordinators experienced a significantly higher level of pedagogical empowerment in comparison to technological empowerment. $\mathrm{T}(141)=2.57, \mathrm{P}<.05$

Table 2 shows the means and standard deviations of empowerment patters according to the different positions of ICT leaders. 
Table 2: ICT leaders' personal empowerment patterns, means and standard deviations.

\begin{tabular}{|c|c|c|c|c|c|c|c|}
\hline & & \multicolumn{2}{|c|}{$\begin{array}{l}\text { School ICT Co- } \\
\text { ordinators- } \\
\text { Novice }\end{array}$} & \multicolumn{2}{|c|}{$\begin{array}{l}\text { School ICT } \\
\text { Coordinators- } \\
\text { Seniors }\end{array}$} & \multicolumn{2}{|c|}{$\begin{array}{l}\text { Regional } \\
\text { ICT Advi- } \\
\text { sors }\end{array}$} \\
\hline & & $\mathbf{M}$ & SD & $\mathbf{M}$ & SD & $\mathbf{M}$ & SD \\
\hline \multirow[t]{3}{*}{$\begin{array}{l}\text { Technological } \\
\text { empowerment }\end{array}$} & $\begin{array}{l}\text { The experience benefited my } \\
\text { field work }\end{array}$ & 4.11 & 0.79 & 4.44 & 0.63 & 4.24 & 0.62 \\
\hline & $\begin{array}{l}\text { The experience enriched me in } \\
\text { the technology domain }\end{array}$ & 3.92 & 0.96 & 4.37 & 0.76 & 4.07 & 0.79 \\
\hline & $\begin{array}{l}\text { Total items of technological } \\
\text { empowerment }\end{array}$ & 4.01 & 0.80 & 4.41 & 0.59 & 4.16 & 0.62 \\
\hline \multirow[t]{5}{*}{$\begin{array}{l}\text { Pedagogical } \\
\text { empowerment }\end{array}$} & $\begin{array}{l}\text { The experience enriched me in } \\
\text { the pedagogical domain }\end{array}$ & 4.02 & 0.85 & 4.33 & 0.71 & 4.29 & 0.64 \\
\hline & $\begin{array}{l}\text { The training inspired me to } \\
\text { continue learning }\end{array}$ & 4.18 & 0.80 & 4.47 & 0.59 & 4.29 & 0.84 \\
\hline & $\begin{array}{l}\text { The meetings exposed me to a } \\
\text { wide variety of ideas }\end{array}$ & 4.06 & 0.83 & 4.44 & 0.63 & 4.22 & 0.72 \\
\hline & $\begin{array}{l}\text { The training contributes to my } \\
\text { skills as a leading teacher in the } \\
\text { field of assimilating } 21 \text { 'st cen- } \\
\text { tury skills }\end{array}$ & 4.19 & 0.83 & 4.51 & 0.59 & 4.24 & 0.58 \\
\hline & $\begin{array}{l}\text { Total items of pedagogical } \\
\text { empowerment }\end{array}$ & 4.11 & 0.73 & 4.44 & 0.56 & 4.26 & 0.56 \\
\hline
\end{tabular}

\section{School Strengths following ICT Implementation- ICT Leaders' Viewpoint}

To identify the schools' strengths following ICT implementation, a content analysis was performed on ICT leaders' response to "describe at least one significant strength in the school following the implementation of ICT during this past year." The findings revealed nine fields in which the school improved following the ICT plan. These nine school strengths are described here in detail:

(1) Technological assimilation: this strength was reported in $27 \%$ of the total statements. In these statements, ICT leaders reported on the enhanced use of computers as the school strength.

"Each of the teachers enters the classroom with his computer, it means a lot... they (the teachers) started to communicate with each other through email... even the senior teachers, who have less technological knowledge, fit in." (Translated from Hebrew)

(2) Dialogue: this strength was reported in $16 \%$ of the total statements. In these statements, ICT leaders remarked that following the use of ICT, the dialogue between teachers, parents and students improved markedly.

"ICT has turned the school into a "hive", has strengthened the teacher-student-parent connection ... the school site is used as a communication tool with the parents". (Translated from Hebrew) 
(3) Student empowerment: this strength was reported in $14 \%$ of the total statements. In these statements, the ICT leaders report that ICT markedly improved the level of interest and motivation of the students and also enhanced their abilities.

"Also, the students who are the main issue were very very interested in ICT-based lessons, teachers reported fewer discipline problems; the weaker students started to participate more in class and showed more interest... "(Translated from Hebrew)

(4) Information sharing: this strength was reported in $12 \%$ of the total statements. In these statements, the ICT leaders refer to the ways in which ICT contributed to the sharing of professional material and knowledge between teachers.

"Cooperation between teachers in constructing and transmission of ICT-based lessons... I can point to the remarkable team work, cooperation, assistance and support between those (teachers) for whom ICT 'runs in their blood' and those who are more frightened and insecure" (Translated from Hebrew)

(5) Teacher empowerment: this strength was reported in $9 \%$ of the total statements. In these statements, the ICT leaders refer to the direct impact of ICT implementation on the sense of empowerment teachers' experience. This process of empowerment is a result of the technological and pedagogical tools teachers acquire and their effect on their sense of satisfaction, success, interest and professional diversity.

"I can see and feel the enthusiasm of the teachers, especially I see the senior teachers, who have been functioning in the system for many years, and are a bit worn out, that ICT 'gave them life', increased their motivation. I can see the enthusiasm of teachers to integrate these tools in their teaching method." (Translated from Hebrew)

(6) Management optimization: this strength was reported in $9 \%$ of the total statements. In these statements, the ICT leaders refer to the way the ICT plan is used to assist the construction of effective work processes at the level of the organization and management of the school.

"Digital communication between teachers, parents and students: information that passes through this triangle on the internet saves paper, resources and is more available." (Translated from Hebrew)

(7) Pedagogical change: this strength was reported in $8 \%$ of the total statements. In these statements, the ICT leaders refer to the ICT plan as one that has a positive influence on the perception of pedagogy and teaching at the school.

"The entry of ICT to the school has brought a new way of thinking on teaching methods, on pedagogy and on the role of a teacher-which is not only to provide information, but also to enable, mediate and 'open new worlds' to his students." (Translated from Hebrew)

(8) Bridging the gaps: this strength was reported in 3\% of the total statements. In these statements, the ICT leaders refer to the way ICT can assist in bridging the gaps between students and overcoming the variance that naturally exits among students. ICT can allow, on the one hand, support of weak students, and on the other hand can challenge and motivate gifted students.

"The students can express themselves more creatively, thus responding to the extensive diversity among students. Each one (student) can find his own niche to express himself." (Translated from Hebrew)

(9) Community visibility: this strength was reported in 3\% of the total statements. In these statements, the ICT leaders refer to the way the school's website can promote and improve the image of the school as it is perceived in the community.

"Exposing the school's work has improved the school's image in the community." 
From the nine strengths that were revealed, we identified three aspects regarding school strengths: pedagogical, technological, and organizational. These aspects are elaborated here.

The pedagogical aspect - in which the ICT leaders refer to the way assimilating ICT can contribute to the pedagogy and quality of teaching at the school. This aspect includes the following strengths: dialogue, student empowerment, information sharing, teacher empowerment, pedagogical change, and bridging the gaps.

The technological aspect - in which the ICT leaders refer to the way the school's staff has managed to learn and use the new technology successfully. In this aspect the strength that is implied is the mere use of the technology, without referring to its contribution to the pedagogical or organizational domains.

The organizational aspect - in which the ICT leaders refer to the way assimilation of ICT has contributed to the streamlining of the school as an organization. This aspect includes the following strengths: dialogue, management optimization and community visibility.

Figure 1 illustrates the division of the schools' strengths according to the three aspects: pedagogical, technological, and organizational.

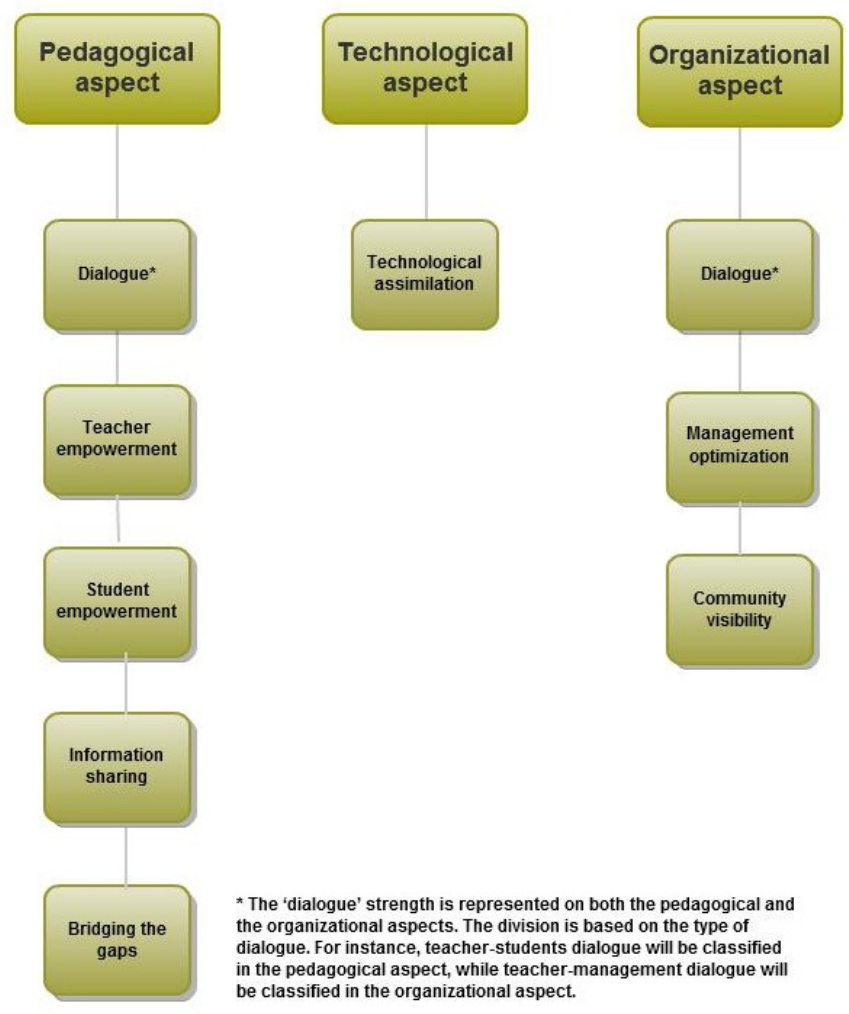

Figure 1. School strengths division in the pedagogical, technological and organizational aspects

Table 3 shows the frequency with which each group of ICT leaders referred to the three school strength aspects. 
Table 3: Frequency of the school strengths aspects among the ICT leaders

\begin{tabular}{lcccc}
\hline \multicolumn{1}{c}{ School strengths aspects } & \multicolumn{5}{c}{ Frequency (percentages) } \\
\hline & $\begin{array}{c}\text { School ICT coordi- } \\
\text { nators- new (\%) }\end{array}$ & $\begin{array}{c}\text { School ICT } \\
\text { coordinators- } \\
\text { seniors (\%) }\end{array}$ & $\begin{array}{c}\text { Regional ICT } \\
\text { advisors (\%) }\end{array}$ & $\begin{array}{c}\text { Total ICT leaders } \\
(\%)\end{array}$ \\
\hline Pedagogical aspect & 51 & 44 & 55 & 50 \\
\hline Technological aspect & 34 & 40 & 28 & 34 \\
\hline Organizational aspect & 16 & 16 & 17 & 16 \\
\hline
\end{tabular}

From Figure 1 and Table 3 it can be seen that most of the school strengths that ICT leaders identified related to the pedagogical aspect. It is worth notice that the pedagogical aspect was most referred to by the Regional ICT Advisors. It is possible that their position as key figures in the leading of pedagogical change at schools is related to this finding.

\section{The Relationship between Personal Empowerment Patterns of ICT Leaders and School Strengths, as Perceived by the ICT Leaders}

In order to examine the possible correlations between personal empowerment of ICT leaders and the schools' strengths following ICT implementation, ANOVA one-way tests were performed to examine the personal empowerment pattern changes as a function of the school strength aspects. This analysis was performed on each group of ICT leaders separately and on the total of ICT leaders. The test results are presented here (see Table 4 for means and standard deviations).

1. Among the new School ICT Coordinators, the test found a significant difference in the measure of technological empowerment as a function of the school strength aspect $[\mathrm{F}(2,139)=3.96$, $\mathrm{p}<.05]$. Post hoc comparisons using Tukey's test showed that novice School ICT Coordinators who reported on pedagogical school strength experienced higher levels of personal empowerment in the technological domain than those who reported technological strength.

2. Among the senior School ICT Coordinators, the test found significant differences in the measure of technological $[\mathrm{F}(2,49)=3.37, \mathrm{p}<.05]$ and pedagogical $[\mathrm{F}(2,49)=4.85, \mathrm{p}<.05]$ empowerment as a function of school strength aspect. Post hoc comparisons using Tukey's test showed that senior School ICT Coordinators who reported on pedagogical school strength experienced higher levels of personal empowerment in the pedagogical and technological domains than those who reported technological strength.

3. Among the total ICT leaders, the test found significant differences in the measure of technological $[\mathrm{F}(2,222)=4.98, \mathrm{p}<.01]$ and pedagogical $[\mathrm{F}(2,222)=5.36, \mathrm{p}=.005]$ empowerment as a function of school strength aspect. Post hoc comparisons using Tukey's test showed that ICT leaders who reported on pedagogical school strength experienced higher levels of personal empowerment in the pedagogical and technological domains than those who reported technological strength.

The analyses shown above indicate that there is a significant correlation between high pedagogical and technological personal empowerment and school strength in the pedagogical aspect.

However, for the Regional ICT Advisors this correlation was not found. One possibility is that the Regional ICT Advisors work with several schools in parallel. Thus, their sense of empowerment is not directly linked to the schools' strengths and is more affected by their position as ICT leaders. 
Table 4: Pedagogical and technological empowerment of ICT leaders as a function of the school strength.

\begin{tabular}{|c|c|c|c|c|c|}
\hline & \multirow[t]{2}{*}{ School strength } & \multicolumn{2}{|c|}{$\begin{array}{c}\text { Technological empowerment } \\
\text { of ICT Leaders }\end{array}$} & \multicolumn{2}{|c|}{$\begin{array}{c}\text { Pedagogical empower- } \\
\text { ment of ICT leaders }\end{array}$} \\
\hline & & $\mathrm{M}$ & SD & $\mathrm{M}$ & SD \\
\hline \multirow{3}{*}{$\begin{array}{l}\text { School ICT } \\
\text { coordinators- } \\
\text { new }\end{array}$} & Technological & 3.80 & 0.82 & 3.96 & 0.75 \\
\hline & Organizational & 3.82 & 0.75 & 3.97 & 0.84 \\
\hline & Pedagogical & 4.18 & 0.76 & 4.24 & 0.67 \\
\hline \multirow{3}{*}{$\begin{array}{l}\text { School ICT } \\
\text { coordinators- } \\
\text { seniors }\end{array}$} & Technological & 4.15 & 0.63 & 4.16 & 0.60 \\
\hline & Organizational & 4.43 & 0.53 & 4.39 & 0.48 \\
\hline & Pedagogical & 4.63 & 0.50 & 4.70 & 0.44 \\
\hline \multirow{3}{*}{$\begin{array}{l}\text { Regional ICT } \\
\text { Advisors }\end{array}$} & Technological & 4.18 & 0.51 & 4.07 & 0.53 \\
\hline & Organizational & 4.07 & 0.67 & 4.32 & 0.45 \\
\hline & Pedagogical & 4.20 & 0.67 & 4.35 & 0.61 \\
\hline \multirow{3}{*}{$\begin{array}{l}\text { Total ICT } \\
\text { leaders }\end{array}$} & Technological & 3.94 & 0.76 & 4.02 & 0.69 \\
\hline & Organizational & 3.99 & 0.72 & 4.12 & 0.73 \\
\hline & Pedagogical & 4.26 & 0.72 & 4.34 & 0.64 \\
\hline
\end{tabular}

Table 4 shows means and standard deviations of the pedagogical and technological empowerment measures of the ICT leaders. This data is represented for each group of ICT leaders individually and for the total of ICT leaders. Also, each group is divided according to the school strength that was reported by the ICT leader. This table shows that ICT leaders who reported on pedagogical school strength also show higher levels of pedagogical and technological empowerment.

\section{Summary and Discussion}

The Israeli Ministry of Education, like in many other countries, has initiated reforms that are intended to adjust the education system to the 21 st century, which is characterized by rapid change, globalization, and exposure to information. These changes create the need to integrate computer skills into school culture as a pedagogical tool and as an administrative tool for instructional and learning activities (Israeli Ministry of Education, 2012). The Israeli reform, called "Adjusting the education system to the 21 st century" was designed to meet these specific needs by incorporating ICT leaders that would lead the implementation of ICT skills at the school. As leaders of such organizational change, we assumed the ICT leaders would experience a sense of personal empowerment. However, we would not sure as to how this empowerment could affect the school and assist the organizational change. Thus, the current study set out to examine evidence of empowerment among the ICT leaders and its effect on the schools strengths following ICT implementation. We found a positive correlation between patterns of empowerment of ICT leaders and its impact on school strengths. More specifically, we found that ICT leaders who reported pedagogical change at the school following ICT implementation also experienced high levels of pedagogical and technological empowerment. In the discussion section we will suggest theoretical models based on our results and discuss the practical implications of our results. 


\section{Dimensions of Leaders' Empowerment and its Impact on School Strengths}

The findings suggest that ICT leaders - School ICT Coordinators, both novice and seniors, and Regional ICT Advisors - experienced a sense of empowerment stemming from the year of the training and guiding process. Pedagogical empowerment was reported as significantly higher than empowerment focused on technology alone. In fact, we can say that ICT leaders reported empowerment sensed due to the acquisition of technological pedagogical knowledge as it is presented by Mishra \& Koehler (2006). This innovative knowledge is required from all teachers who intend to implement technology in their instruction in order to enrich their pedagogical work and make it up-to-date.

In addition to the above, it should be noted that the findings indicate that the seniors ICT school leaders reported a higher empowerment experience combining pedagogical and technological teaching, than the new ICT school leaders. This finding demonstrates the importance of long-term processes for optimal implementation of ICT as a tool for empowerment pedagogy (Shamir-Inbal \& Kally, 2011).

The current study demonstrates a positive correlation between empowerment of ICT leaders and implementing of school strengths. Thus, our results suggest that the empowerment of the ICT leaders has contributed to the enhancement of pedagogical change at the school. Similar effects were found in studies that showed that empowering teachers has positive effect on organizational change and growth (e.g., Enderlin-Lampe, 2002; Irwin, 1996). Also, this correlation suggests the other direction is possible as well. Meaning, the schools strengths following the ICT implementation could contribute to the ICT leaders' sense of empowerment. Schools' staff tends to relate organizational success as a personal achievement and as such, it contributes to their personal empowerment as well (Avidov-Ungar, Friedman, \& Olstein, 2011). Clearly, ICT leaders could also assert their personal contribution to the process of ICT implementation at the school. Thus, we assumed that ICT leaders' empowerment and school strengths are related processes that affect each other continuously in a cycle of impact. This cycle reinforces both the leaders and the schools. We also believe that this cycle of mutual influence enables the leaders to be a bridge between the demands of the system (top-down) and the needs of the school - the accepted norms, the staff and its motivation (bottom-up) (Fishman et al., 2004). Figure 2 illustrates the manner in which this mutual influence occurs.

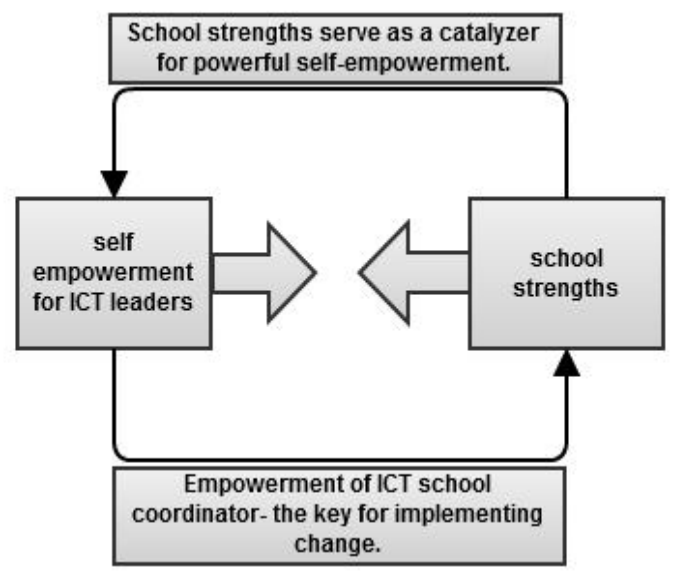

Figure 2: Contact circuits between self-empowerment of ICT leaders and school strengths. 
Implementation of ICT in schools will be more successful if the organization's culture and vision emphasize the major and central role of technology in the organization (Avidov-Ungar, 2010; Shamir-Inbal et al., 2009). These school patterns influence the goals for ICT integration and their impact on the curriculum (Yuen, Law, \& Wong, 2003). In this paper we claim that in addition to the correlation between leaders' performance and schools' characteristics and staff, as shown in the Yuen et al., (2003) paper, it should be acknowledged that empowering of ICT leaders creates schools' strengths as well. In fact, this is the core of successful ICT implementation. We draw out these new patterns in Table 5.

Many studies have shown that school ICT leadership is needed for long-term sustainability of school implementation (Yuen et al., 2003). Empowering of ICT leaders affects directly the characteristics of an implementing school, and enables it to act as a 'change implementing organization', through integrating technology in school. That makes it a supporting organization, where there is a mutual relationship between the leaders' empowerment, the school's strengths and their impact on its characteristics and function. Table 5 shows these reciprocal relationships between school characteristics, leading role and the patterns of leaders' self-empowerment.

Table 5: Reciprocal relationships: school characteristics and ICT leaders' self-empowerment.

\begin{tabular}{lll}
\hline \multicolumn{1}{c}{ School characteristics } & \multicolumn{1}{c}{ Leading role } & $\begin{array}{c}\text { Pattern of empow- } \\
\text { erment }\end{array}$ \\
\hline $\begin{array}{l}\text { Mainly used for ICT-technical } \\
\text { and administrational issues. }\end{array}$ & $\begin{array}{l}\text { Staff follows guidelines of the Ministry of } \\
\text { Education - "top-down" activity. }\end{array}$ & $\begin{array}{l}\text { Technological } \\
\text { strength emphasized. }\end{array}$ \\
$\begin{array}{l}\text { School culture promotes changes } \\
\text { in curriculum intended to pro- } \\
\text { mote teaching and learning. }\end{array}$ & $\begin{array}{l}\text { The manager's right hand. Leading a vi- } \\
\text { sion. Agents of change. Combine "top } \\
\text { down" guidelines with "bottom up" moti- } \\
\text { vation and self-empowerment among } \\
\text { teachers. }\end{array}$ & $\begin{array}{l}\text { Pedagogical strength } \\
\text { emphasized. }\end{array}$ \\
\hline
\end{tabular}

\section{School Strengths}

Statistical analyses were conducted to examine the relationship between self-empowerment of ICT leaders and school strengths. We found that ICT leaders who reported higher selfempowerment for pedagogical and technological issues also reported schools' pedagogical strength, compared to ICT leaders who mainly reported a technology self-empowerment.

Based on this finding, we built the model shown in Figure 3. The model demonstrates that pedagogical strength is a more advanced stage of the ICT implementation process, and it is based on the combination of pedagogical and technological self-empowerment. 


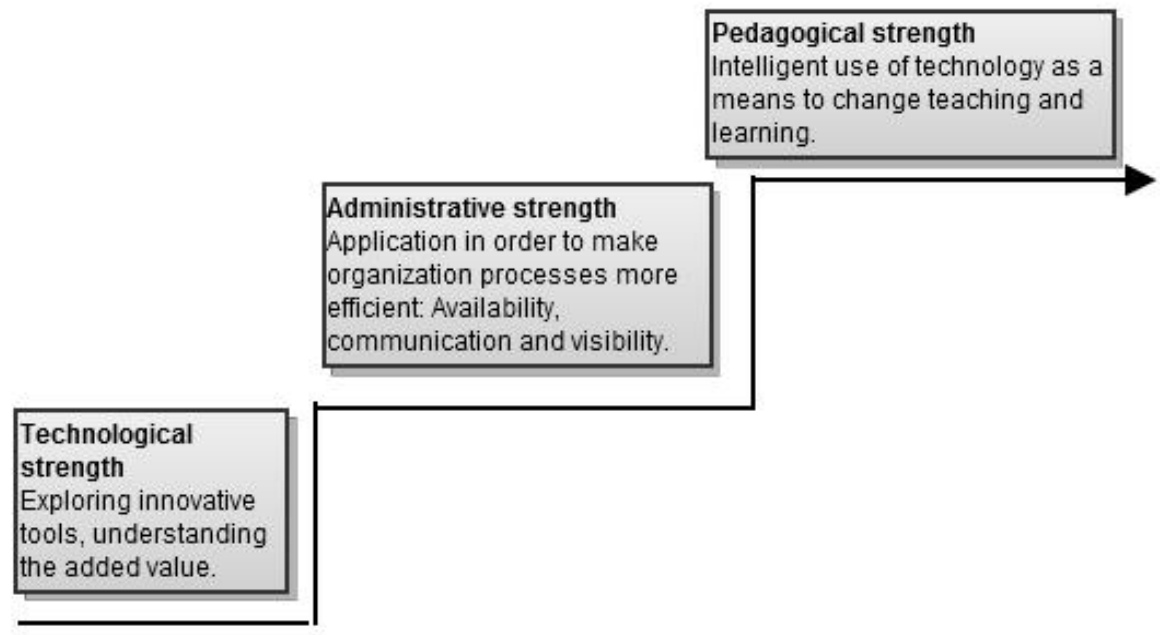

Figure 3: Model of a gradual ICT assimilation process in schools.

The implementation process begins with the study of a variety of technological tools and understanding the added value of using them. Further on, a substantial effect on the conduct of the school as an effective organization has been observed (availability, communication, and visibility). Finally, a systemic change is caused in the school, which affects teachers' views of teaching and learning. Such a change is reflected by displaying a positive attitude regarding the implementation requirements of the system. When it is understood that the importance of technology itself is not the main goal, but its use as a tool for pedagogical change that enables adaptation of the teaching and learning to the 21 st century, it will be possible to implement technology in school activities.

\section{Conclusion and Practical Implications}

This study points out the importance of the personal empowerment process of ICT leaders and the school level as catalyzers to enhance strengths in implementing ICT in school. Teachers who are appointed as ICT school leaders or as regional ICT advisors are known as "change leaders".

These teachers act to extend the implementation among other teachers in school, and thus expand the core of teachers who implement ICT. Rogers would term them as "first adopters" (Rogers, 1995). Collaboration between schools' ICT leaders and other teachers helps to create staff motivation, commitment, and mutual responsibility. If the leaders' empowerment process continues, it is expected that, over time, ICT use will be integrated among the majority (the "followers") and may even pull in some of the objectors (Shamir-Inbal \& Kally, 2009). This way, the group of ICT-implementing teachers will grow, and new teachers will take part in the innovative spirit of the school.

On the theoretical level, this study proposes a model that considers the technology implementation process in schools as a tool to streamline the school system and promote systemic change in school pedagogy. Our models can shed light on the process of ICT implementation at schools' and how it relates to the ICT leaders empowerment. We suggest future studies should construct quantitative measures for evaluating the schools strengths, thus enabling further validation of the models we purposed. Also, these measures could assist principals in their evaluation of the effectiveness of ICT reforms. 
On the practical level, these findings highlight the importance of professional guidance of ICT leaders as promoters of systemic change in schools at the regional level. First, our findings suggest that the implementation of ICT is a process that takes time and effort in the instructional system. Thus, we suggest building a long term meaningful process that includes personal empowerment of ICT leaders, creating school strength, impact on school staff and its practice. All of these will allow optimal integration of technology as a tool for teaching and thereby create a significant pedagogical awaited change. To implement constructivist principles and collaborative learning, teachers have to specialize over time, and have significant experience with ICT in the classroom, as well as planning and designing ICT-based learning activities (Shamir-Inbal \& Kali, 2009). Second, our gradual model of ICT assimilation emphasizes the importance of technological knowledge as a step towards developing a significant pedagogical change. However, it stresses that focusing solely on the acquisition of technological knowledge will not lead to optimal assimilation of ICT at the school. Thus, we recommend ICT reforms will combine training and close guidance in the technological domain, with a more comprehensive approach that emphasizes using ICT as an instrument for pedagogical innovation and organizational change. The Israeli educational system is managed in a systematic approach, in which significant changes in the organization tend to be is inspired by national reforms (i.e. the national ICT reform). This systematic approach can assist when constructing broad organizational changes that require significant resources for optimal assimilation (Avidov-Unger \& Shimoni, 2013). Thus, we believe are findings are universal and can be applicable in many countries who choose a systematic policy of organizational changes.

\section{References}

Avidov-Ungar, O. (2010). "Islands of Innovation" or "Comprehensive Innovation" assimilating educational technology in teaching, learning, and management: A Case Study of school networks in Israel. Interdisciplinary Journal of E-Learning and Learning Objects, 6, 259-280. Retrieved from http://www.ijello.org/Volume6/IJELLOv6p259-280Avidov704.pdf

Avidov-Ungar, O., \& Eshet-Alkalai, Y. (2011a). Teachers in a world of change: Teachers' knowledge and attitudes towards the implementation of innovative technologies in schools. Interdisciplinary Journal of E Learning and Learning, 7, 291 - 303. Retrieved from http://www.ijello.org/Volume7/IJELLOv7p291-303Avidov-Ungar767.pdf

Avidov-Ungar, O., \& Eshet-Alkakay, Y. (2011b). The Islands of Innovation model: Opportunities and threats for effective implementation of technological innovation in the education system. Issues in Informing Science and Information Technology, 8, 363-376. Retrieved from http://iisit.org/Vol8/IISITv8p363-376Avidov213.pdf

Avidov-Ungar, O., \& Friedman,Y. (2011). Empowering teachers -Eessence and models. Henrietta Szold Institute, Jerusalem [Hebrew].

Avidov-Ungar, O., Friedman,Y., \& Olstein., E. (2011). Patterns of empowerment among teachers with a leading role in primary schools in Israel: limited empowerment, rewarding empowerment and changeenhancing empowerment. Studies in Educational Administration and Organization, 32, 153-184. [Hebrew]

Avidov-Ungar, O., \& Shimoni, S. (2013). On the continuum: Training, specialization, and teachers' professional development - Policy, theory, and practice. Mofet Institute, Tel-Aviv [Hebrew].

Bandura, A. (1997). Self-efficacy - The exercise of control. New York, NY: Freeman.

Carter, E. (2008). Successful change requires more than change management. The Journal for Quality \& Participation, 31(1), 20-23.

Creswell, J. W. (2007). Qualitative inquiry and research design: Choosing among five traditions. Thousand Oaks: Sage Publications. 
Cribner, J.P., Truell, A. D., Hager, D. R., \& Srichai, S. (2001). An exploratory study of career and technical education teacher empowerment: Implications for school leaders. Journal of Career and Technical Education, 18(1), 46-57.

Darling-Hammond, L., \& Bransford, J. (Eds.). (2005). Preparing teachers for a changing world: What teachers should learn and be able to do. San Francisco, CA: Jossey-Bass.

Darling-Hammond, L., Wei, R. C., Andree, A., Richardson, N., \& Orphanos, S. (2009). State of the profession: Study measures status of professional development. Journal of Staff Development, 30(2), 42-44, 46-50.

Day, C., \& Gu, Q. (2007). Variations in the conditions for teachers' professional learning and development: Sustaining commitment and effectiveness over a career. Oxford Review of Education, 33(4), 423-443.

Doering, A., Veletsianos, G., Scharber, C., \& Miller, C. (2009). Using the technological, pedagogical, and content knowledge framework to design online learning environments and professional development. Journal of Educational Computing Research, 41(3), 319-346. doi:10.2190/EC.41.3.d

Edwards, J. L., Green, K. E., \& Lyons, C. A. (2002). Personal empowerment, efficacy, and environmental characteristics. Journal of Educational Administration, 40(1), 67-86.

Enderlin-Lampe, S. (2002). Empowerment: Teachers perceptions, aspirations and efficacy. Journal of Instructional Psychology, 29(3), 139-46.

Fishman, B., Marx, R., Blumenfeld, P., Krajcik, J. S., \& Soloway, E. (2004). Creating a framework for research on systemic technology innovations. Journal of the Learning Sciences, 13(1), 43-76.

Fraser, C., Kennedy, A., Reid, L., \& Mckinney, S. (2007). Teachers' continuing professional development: Contested concepts, understanding and models, Journal of In-Service Education, 33(2), 153-169.

Fullan, M. (2001). The new meaning of educational change (3rd ed.). New York: Teachers College Press.

Hadjithoma-Garstka. (2011). The role of the principal's leadership style in the implementation of ICT policy. British Journal of Educational Technology, 42(2), 311-326.

Hargreaves, A. (2005). Educational change takes ages: Life, career and generational factor in teacher emotional responses to educational change. Teaching and Teacher Education, 21, 967-983.

Hargreaves, A., \& Goodson, I. (2006). Educational change over time? The sustainability and nonsustainability of three decades of secondary school change and continuity. Educational Administration Quarterly, 42(1), 3-41.

Irwin, J. W. (1996). Empowering ourselves and transforming schools: Educators making a difference. Albany, New York: State University Press.

Israeli Ministry of Education. (2012). Retrieved from http://cms.education.gov.il/EducationCMS/Units/MadaTech/hatamat_marechet_21

Kaufman, J. (2009). Learning to be an American. International Review of Qualitative Research, 1(4), 481490.

Kennedy, A. (2005). Models of continuing professional development: a framework for analysis. Journal of In-Service Education, 31(2), 235-250.

Kieffer, C. A. (1983). Citizen empowerment: A developmental perspective. Prevention in Human Services, $1,9-36$.

Kozma, R.B. (2008). Comparative analysis of policies for ICT in Education. Springer International Handbooks of Education, 20, 1083-1096, DOI: 10.1007/978-0-387-73315-9_68

Kuijpers, J. M., Houtveen A. A. M., \& Wubbels, T. (2010). An integrated professional development model for effective teaching. Teaching and Teacher Education, 26(8), 1687-1694.

Levin, B., \& Fullan, M. (2008). Learning about system renewal. Journal of Educational Management, Administration and Leadership, 36 (2), 289-303. 
Mioduser, D., Nachmias, R., Forkosh, B. A., \& Tubin, D. (2004). Sustainability, scalability and transferability of ICT-based pedagogical innovations in Israeli schools. Education, Communication \& Information, 4(1), 71-82.

Mishra, P., \& Koehler, M. J. (2006). Technological pedagogical content knowledge: A framework for teacher knowledge. Teachers College Record, 108(6), 1017-1054.

Newhouse, P. (2010). School leadership critical to maximizing the impact of ICT on learning. Centre for Schooling and Learning Technologies, Edith Cowan University Melbourne, Australia.

Ogobonna, E., \& Harris L. C. (2003). Innovation organizational structure and performance. Journal of Organizational Change Management, 16(5), 512-533.

Pajares, F. M., \& Miller, M. D. (1994). Role of self efficacy and self concepts beliefs in mathematical problem solving: A path analysis. Journal of Educational Psychology, 86(2), 193-203.

Peled, Y., Kali, Y., \& Dori, Y. J. (2007). Interaction between science teachers and school principals and its influence on technology implementation: A retrospective analysis. In Y. Eshet, A. Caspi \& Y. Yair (Eds.), Proceedings of the 2nd Chais conference: Instructional Technologies Research, Learning in the Technological Era (pp. 117-121). Ra'anana: The Open University.

Polly, D., \& Mims, C. (2009). Designing professional development to support teachers' TPACK and integration of Web 2.0 technologies. In T. Kidd \& I. Chen (Eds), Wired for Learning: Web 2.0 Guide for Educators, (pp. 301-316). Charlotte, NC: Information Age Publishing.

Rogers, E. M. (1995). Diffusion of innovations. New York: Free Press.

Sarason, S. B. (1995). The school culture and processes of change. In S. B. Sarson (Ed.), School change The Development of A point of View (Ch.6, pp.65-84). New York and London: Teacher College, Columbia University.

Shamir-Inbal, T., Dayan, J., \& Kali, Y.(2009). Assimilating online technologies into school culture. Interdisciplinary Journal of E-Learning and Learning Objects, 5, 307-334. Retrieved from http://www.ijello.org/Volume5/IJELLOv5p307-334Samir-Inbal675.pdf

Shamir-Inbal, T., \& Kali, Y. (2009). Teachers as designers of online activities: The role of socioconstructivist pedagogies in sustaining implementation. Design Principles \& Practices: An International Journal, 3(1), 89-100.

Shamir-Inbal, T., \& Kali, Y (2011). Systemic model for implementing ICT in school culture. In G. Korez \& D. Chen (Eds), ICT, learning \& teaching. Center for Academic Publishing Or Yehuda. [Hebrew]

Tyack, D., \& Cuban, L. (1995). Tinkering toward utopia: A century of public school reform. Cambridge, Massachusetts: Harvard University Press.

Vaillant, D. (2005). Educational reform and the role of teachers. Prelac Journal, 1, 38-51.

White, S. (2007). Critical success factors for e-learning and institutional change - Some organizational perspectives on campus-wide e-leaning. British Journal of Educational Technology, 38(5), 840-850.

Yuen, H. K., Law, N. W. Y., \& Wong, K. C. (2003). ICT implementation and school leadership: Case studies of ICT integration in teaching and learning. Journal of Educational Administration,41(2), 158-170. Retrieved from http://hub.hku.hk/bitstream/10722/42273/1/79396.pdf?accept=1

Zimmerman, J. (2006). Why some teachers resist change and what principals can do about it. NASSP Bulletin, 90(3), 238-249. 


\section{Biographies}

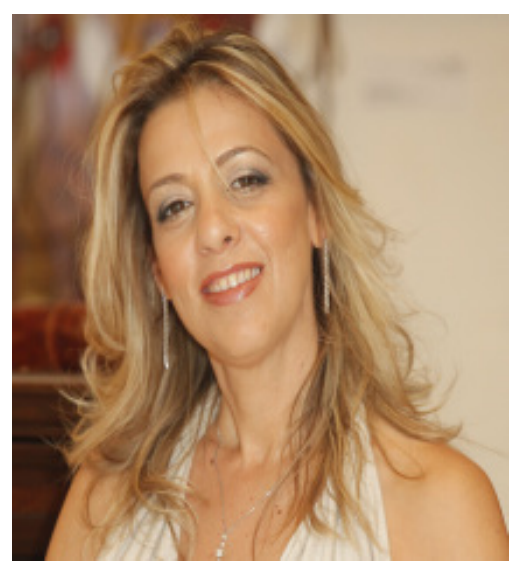

Dr. Orit Avidov-Ungar is the Head of Research Authority and senior lecturer at the School of Education Systems Management at Achva Academic College she is also a member of the faculty of the Open University in Israel. She heads the specialization in professional development at the Mofet Institute and is the academic advisor to the Ministry of Education in Israel management in the implementation of innovative technology systems and the professional development of teachers. Her research studies deal with the implementation of innovative technologies in education systems, the empowerment and professional development of teachers, and leading organizational change in education systems.

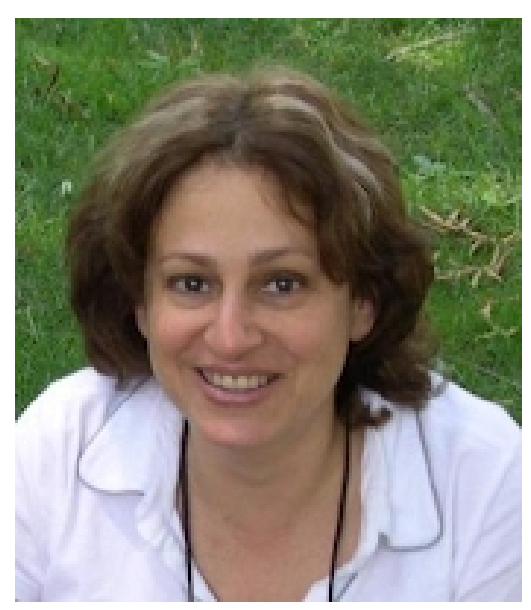

Dr. Tamar Shamir-Inbal is a pedagogical coordinator and academic advisor for the Israeli Ministry of Education. Tamar leads professional development programs and teacher training courses, which enhance digital teaching and learning in schools, and empowerment of ICT Leaders and principals. Tamar is a member of the Teaching and Design (TeLTaD) research group at the University of Haifa and also a moderator of courses of "ICT implementation: Practice \& Theory" at the Israeli Open University. Her research studies focus on professional development of teachers adopting technology-enhanced strategies for their everyday instruction, design and implementation of socio-constructivist pedagogies in online activities. 